
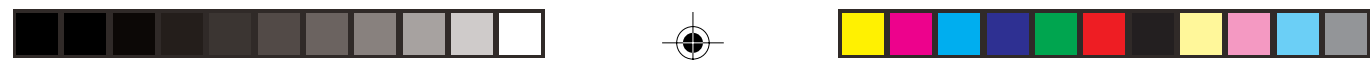

\title{
3. From Fiji to Fallujah: The war in Iraq and the privatisation of Pacific security
}

\begin{abstract}
Since the invasion of Iraq in 2003, private security companies from the United Kingdom and United States have been seeking personnel for their operations in the Middle East, and many hundreds of Fijians have signed up. The privatisation of security, a growing trend in the Middle East and Africa, has reached the shores of the South Pacific and governments have little control over former army personnel employed by private military contractors. This article documents the recruitment of Fijian military personnel for service in Iraq and Kuwait, and the casualties that they have faced. The engagement of former military personnel as private military contractors has spilt over into the Pacific as well-from the 1997 Sandline crisis to current events in Bougainville. Since November 2005, the governments of Fiji, Papua New Guinea and Solomon Islands have tried to resolve a crisis caused by the presence of former Fijian soldiers in Bougainville.
\end{abstract}

NIC MACLELLAN

Journalist and researcher, Melbourne

$\mathrm{L}$ EDUA Atalifo was worried. Her husband Jim had been killed in Iraq, but his body was mistakenly sent to the United States, while another body arrived in Fiji. Five children had lost their father and it was a bit much to lose the corpse as well. It took some weeks and an anxious wait before the correct body was sent home to Wakanisila settlement in Suva, the capital of the Fiji Islands.

The deaths of Waisea Jim Atalifo and his Fijian colleague Timoci Lalaqila

PACIFIC JOURNALISM REVIEW 12 (2) 200647 


\section{ECO-JOURNALISM AND SECURITY}

are a stark reminder of the privatised war being waged behind the headlines of 'Operation Iraqi Freedom'. Lalaqila and Atalifo were killed along with nine others in April 2005, when Iraqi insurgents shot down their helicopter, north of Baghdad. Early media reports said two Filipinos had died - no doubt reporters found it hard to imagine what two Fiji Islanders were doing aboard a Bulgarian-crewed Russian helicopter in the Middle East!

But today more than 1000 Fijians are working for private corporations in Iraq and Kuwait in security, transport and training. Many other Pacific Islanders are serving in Iraq as members of the American and British armed forces. As the US and allied armies are overstretched in occupied Iraq and face growing public concern over the number of casualties, an estimated 20,000 private soldiers have been recruited for security and training jobs in the conflict zone (ASPI, 2005; Isenberg, 2006). Private security operations have become big business for corporations such as DynCorp, Vinnell, Kroll, ArmorGroup and Global Risks Strategies

\section{Helicopter deaths}

The recruitment of Atalifo, a former Fiji police officer, and Lalaqila, a former soldier of the Republic of Fiji Military Forces (RFMF), reflects the path taken by hundreds of other Fijians. The two men initially signed up with the British corporation Global Risk Strategies in 2003, to work as part of a security team assigned to protect diplomats in Iraq. But they later changed employers to get better conditions, signing a five-year contract to work with transport company Skylink USA in early 2005. They were among 20 Fijians working as security guards with Skylink, based in Baghdad and Basra.

Soon after the invasion of Iraq, the US Agency for International Development (USAID) awarded the Washington-based corporation Skylink Air and Logistics Support (USA) Inc. a contract to manage short-term airports in Baghdad, Basra and Mosul. Later, Skylink became the overall manager of Baghdad International Airport and Basra Airport, assisted by the Australian transport company Patrick Corporation. Although Skylink stresses its role as a transport and logistics service, it is involved in military operations from Basra airport, as explained on its website:

Currently, in addition to numerous contractors, the Iraqi Air Force moved to our newly-expanded camp to set up operations. Working with liaison officers from the US military, Iraqi pilots will be learning to fly a

48 PACIFIC JOURNALISM REVIEW 12 (2) 2006 

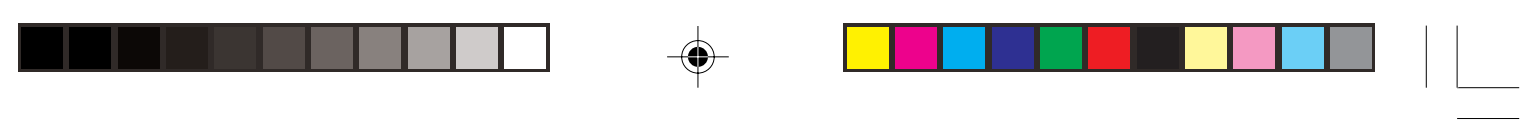

ECO-JOURNALISM AND SECURITY

special aircraft used for reconnaissance missions. These pilots will work closely with other elements of the Iraqi government, including military and law enforcements units, to protect and preserve national assets. (Skylink, 2006)

Skylink USA also maintains air links between Kuwait and Iraq using Russian Antonov aircraft. The company runs two Russian Mi- 8 helicopters for charter by private or government interests, to avoid road travel on routes still considered too dangerous because of attacks by Iraqi insurgents. On 21 April 2005, Lalaqila and Atalifo were travelling on one of Skylink's Mi-8 helicopters when it was shot down by Iraqi insurgents with a rocket propelled grenade. The two Fijian security guards, three Bulgarian crew and six Americans on board were killed, although a group calling itself the Islamic Army in Iraq claimed to have captured a survivor and later executed him (Nadore 2005; Fiji Government 2005a; Tyson, 2005).

The six Americans were working for Blackwater Security Consulting, which claims to be 'the most comprehensive private military company in the world' (Blackwater 2005). Blackwater provides protection for US officials in Iraq - at the time, it had a US\$21 million contract to provide security for former Coalition Provisional Authority head Paul Bremer and US Ambassador John Negroponte. The company briefly hit the headlines in March 2004, when four employees were killed in Fallujah and their bodies were mutilated by an angry mob-an incident which sparked the first major US assault on Fallujah in April 2004, with 600 civilian deaths.

The US Embassy in Suva honoured the two Fijians in an official statement when they were killed:

The United States deeply values and appreciates the support Fiji and so many of its citizens are providing to international efforts to bring peace, freedom and democracy to the people of Iraq. (US Embassy, 2005).

But as the Atalifo family prepared to bury the father of five on the island of Vanua Levu, it emerged that one of the two bodies repatriated from Iraq to Fiji was one of the American victims. Atalifo's wife Ledua said she was only informed of the blunder after it was broadcast on radio (Fijilive, 2005a). The US government had to apologise for this final indignity, and the funeral was delayed while an American forensic expert carried DNA samples to the United

PACIFIC JOURNALISM REVIEW 12 (2) 200649 

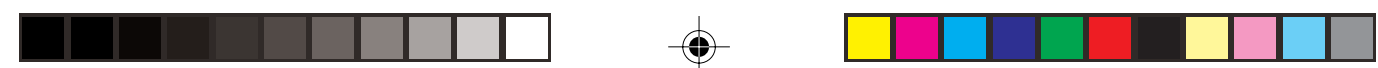

\section{ECO-JOURNALISM AND SECURITY}

States for identification. As Atalifo's body was finally flown home from the United States for burial, the US Embassy 'extended its deepest condolences to the families of both men, saying it understands the mix-up has caused immense anguish, pain and suffering'.

\section{Jobs and remittances}

So far at least 20 Fijians working in Iraq have been killed, with many others wounded. ${ }^{1}$ But in spite of the hazards of the work and criticism from church and non-government organisations, the government of Fiji has not halted the recruitment of former soldiers to travel to the Middle East in a private capacity. Fiji's economy is increasingly reliant on remittances from citizens working overseas. Personal remittances now run to more than F\$200 million a year, earning more than traditional sectors like sugar and garment manufacturing (Mares \& Maclellan, 2006). Much of this amount comes from people who have left Fiji after the 1987 and 2000 coups, including teachers, nurses, doctors and other professionals.

But military recruitment is a growing source of revenue. By mid-2005, there were more than 1000 Fijians working in Iraq and Kuwait, as soldiers, security guards, drivers and labourers. Even though some have been sent home in disgrace, and other returning troops have complained about the failure to obtain the promised benefits and welfare payments to families, more people are signing up for work in the Middle East. As one Fijian security guard wrote home:

\footnotetext{
I must reassure all of you that there is nothing to worry about and that we feel safe and happy. We are all armed, that includes everyone working for the security firm, as well as the church pastors. (Fiji Times, 2005a).
}

The boom in recruiting for Iraq and Kuwait has raised many issues for the Fiji government: the unregulated role of private recruitment contractors, the social impacts on family life, and the capacity of government to support workers with pay disputes or post-deployment health problems. But as private recruitment for the Middle East increased in 2004, Chief Executive in the Prime Minister's Office Joji Kotobalavu told Islands Business magazine that the deployment of Fijians to Iraq could provide a source of income for many families:

50 PACIFIC JOURNALISM REVIEW 12 (2) 2006 

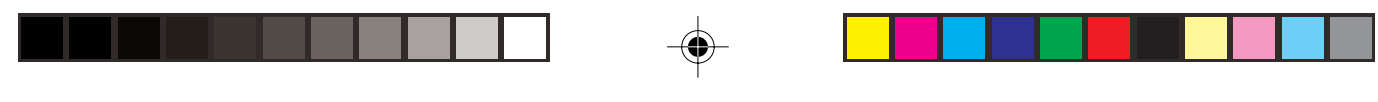

ECO-JOURNALISM AND SECURITY

We all know about the war in Iraq and [the] risks associated with the job, so it's an individual's choice. The government cannot stop anyone because they are exercising their constitutional right and freedom to travel and work anywhere. (Komai, 2004).

In January 2005, the then Minister for Labour Kenneth Zinck announced that 'the government knows that more men are leaving for Kuwait and Iraq and it is a good thing, because it is providing employment for the unemployed. This is one solution to the increasing unemployment rate in the country today' (Fiji Times, 2005b).

\section{Lebanon and peacekeeping}

Beyond the economic imperatives, military service has a long heritage in Fiji, and many indigenous Fijian men have had military training through the Republic of Fiji Military Forces (RFMF). Academics in Fiji have written about the cultural and ideological roots of military tradition in Fiji: Winston Halapua has discussed the links between indigenous Fijian ideologies of lotu (Christianity and Methodism), 'turagaism' (a belief in chiefly rights to leadership) and militarism (Halapua, 2003). Feminist scholar Teresia Teaiwa has charted the links between masculinity, rugby, religion and the bati (warrior) culture in Fiji (Teaiwa, 2005).

While the involvement of the RFMF in domestic politics and coups in 1987 and 2000 has been a source of controversy, the Fiji army has a proud international reputation with a long tradition of supporting UN peacekeeping operations around the world. RFMF soldiers and Fiji police have served in global hotspots like Sinai, Cyprus, Namibia, Kosovo, Zimbabwe, Bougainville, Timor and Lebanon.

For many years, RFMF soldiers played a central role in the United Nations Interim Force in Lebanon (UNIFIL). The UN force operated to maintain peace between the Israeli Defence Force (IDF) and Lebanese guerrilla units in south Lebanon, from 1978 until Israel's withdrawal in May 2000. During that period, hundreds of RFMF soldiers served in Lebanon, providing much needed jobs and remittances but also witnessing the bloodshed of Middle East conflicts. The worst incident came with the April 1996 Qana incident - the bombardment of UNIFIL's Fijian battalion by the Israeli army, which killed 102 Lebanese civilians who were sheltering in the UN com-

PACIFIC JOURNALISM REVIEW 12 (2) 200651 

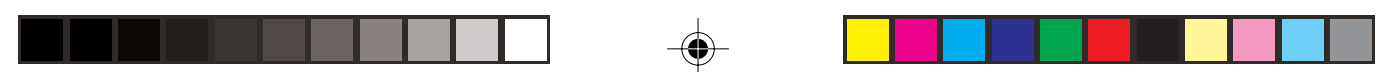

\section{ECO-JOURNALISM AND SECURITY}

pound. ${ }^{2}$ (Ironically, Sakiusa Raivoce, the current recruiter for Global Risks in Fiji, was commander of the Fijian UN contingent in 1996).

Following the American-led invasion of Iraq in 2003, US occupation forces came under attack from a growing insurgency. With restricted numbers of US soldiers and marines and few allies willing to commit troops, the Bush administration sought assistance from private corporations for a range of security, intelligence and force protection roles.

As many serving and reserve RFMF soldiers have Middle East experience, there was a willing pool of recruits in the South Pacific. The United Nations and the RFMF cannot compete with the salaries offered by security corporations, who are desperately seeking experienced personnel to protect infrastructure from Iraqi insurgent attacks and to guard the supply trucks which carry goods to US forces from Kuwait. As recruiter Saula Tuikoro of Sabre International explained:

The government knew that the UNIFIL commitment was coming to end way before the 2002 deadline and many soldiers leaving Lebanon were wondering 'What next?' On arrival in Fiji they were demobilised and what eventually happened was that overnight we had a glut of highlyskilled, highly-trained soldiers doing nothing, despite being skilled in military duties. Members of one reserve battalion were given security duties with Morris Hedstrom supermarkets, but at the end of the day the soldiers realised that what they were being paid was not enough compared to what payment they could demand using their skills. Many of them opted to join security companies, securing work contracts in Iraq and Kuwait. (Fijilive, 2006a).

The loss of skilled officers has hit a small force like the RFMF hard. Army spokesman Lieutenant-Colonel Orisi Rabukawaqa has noted:

We are hurting as far as manning is concerned because officers have been resigning from the force. They have resigned for private reasons like joining the army in Australia, England, New Zealand and a lot joined security companies serving in volatile places like Iraq. (Fijilive, 2006b).

\section{Recruitment for the Middle East}

In 2003, the British-based Global Risks Strategies established a branch in Fiji

52 PACIFIC JOURNALISM REVIEW 12 (2) 2006 
to recruit over 500 former and serving RFMF personnel, to travel to Iraq and provide security for oil fields, installations and government buildings. Former RFMF Lieutenant Colonel Sakiusa Raivoce became the public face of a booming recruitment industry, which was soon joined by other companies. In January 2005, Homeland Security Limited sent a recruiting team to Fiji, seeking 70 men from the police, army or prison service to work as security guards in Iraq. By mid-2005, the company had recruited 181 Fijians to work with the company in the Middle East, attracted by the salaries of F\$3000 (US\$1700) a month - ten times Fiji's estimated poverty line of F\$300 a month.

Homeland is a recruiting agency for the London-based ArmorGroup which operates in 40 countries. In Iraq, the company runs offices in Mosul, Baghdad, and Basra 'providing major corporate and government clients in Iraq with risk assessment and management, close protection, manned guarding, technical security systems, and mine action services' ${ }^{3}$ ArmorGroup also use about 500 Ghurkhas to provide protection for the Baghdad headquarters and transport depots of Kellogg Brown and Root (KBR), a subsidiary of the Halliburton Corporation whose former Chief Executive Officer was US Vice President Dick Cheney.

More than 70 Fijians are working in Iraq with Triple Canopy, a US corporation which boasts that it 'excels in executive protection, site security, and convoy security. Our operators have an average of more than 20 years in the most elite military Special Operations units and are the highest quality personnel in the industry. Our services range from discreet travel companions to heavily armoured, high profile convoy escort'. ${ }^{4}$

In March 2005, another UK-based company registered to open a recruiting office in Fiji, seeking former soldiers for work in the Middle East. Sabre International Security Fiji Ltd, a subsidiary of UK-based Control Solutions, is run by former Special Air Services (SAS) soldiers and has contracts with US companies operating in Iraq. The company initially sought 50 men for six month contracts offering US\$2000-3000 a month. Sabre International Security Fiji director Saula Tuikoro has claimed that 250 Fijian soldiers working in Iraq earned F\$4.9 million between October 2004 and April 2005 (Fiji Times, 2005d). Company director Mike Halligan said: 'We might need up to 1,000 people if we secure more contracts in the near future.' (Fiji Times, 2005c).

According to government figures, 450 Fijians were working in Kuwait and Iraq through Meridian Services Agency by April 2005. Meridian's partner in Kuwait, the Public Warehousing Company (PWC), has a US\$67 mil- 

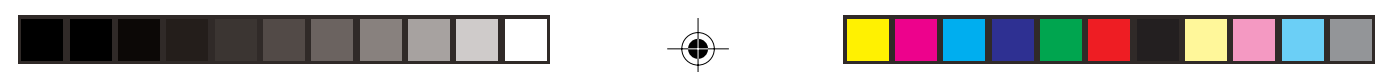

\section{ECO-JOURNALISM AND SECURITY}

lion contract for delivery of supplies to the US armed forces in Iraq, and is seeking Fijian truck drivers, mechanics, storemen and computer operators.

However, 80 Fijians recruited by Meridian Services as drivers in Iraq claimed in July 2005 that they had not been paid for three months. The men said that PWC Logistics had not met the promised pay rates and conditions set out in contracts signed in Fiji, with 100 men either terminated or simply walking off the job. One driver said:

Out of the 350 officers that are left here, we have quite a few who have been terminated, some have just left the job because they are not being paid and only those that have been paid buy food for the whole group. Some of us who could not stand this kind of living have returned to Fiji but the rest are here because we need the money to support our families. (Fiji Times, 2005e).

Up to 15,000 people may have paid a registration fee of $F \$ 150$ to Meridian, in order to be listed for work in Kuwait. (Fijilive, 2005b). Fijian journalist Samisoni Pareti reported that villagers used development funds to pay application fees and that Meridian's recruitment drives have drawn on Methodist Church networks - using church funds to pay for application fees, with the money to be repaid if a job is found in Kuwait (Pareti, 2005).

However, Meridian has organised less than 2000 jobs, even though many more people have paid fees to register for employment. By mid-2005, there were calls for Meridian's local coordinator Timoci Lolohea to be investigated by Fiji's Labour Ministry. The Fiji Times explained:

The people wanted jobs. The domestic job market is not big enough to satisfy everyone's needs. Then in comes Lolohea with a big promise for well-paid jobs in Iraq. Hundreds are hooked. Their prayers have been answered - an opportunity of a lifetime not to be missed. When Lolohea demanded cash from them for fees and fares, the people obliged. Personal savings were withdrawn. Funds that were raised by the community for church or village projects were diverted to the Iraq cause. This was done in the belief that the money they will earn in that faraway land will repay the borrowed funds and more importantly have a big impact on the family bank balance. Personal security becomes secondary. News of suicide bombings and every day killings in Iraq were ignored. Here is an opportunity to earn a reasonably high income and,

54 PACIFIC JOURNALISM REVIEW 12 (2) 2006 

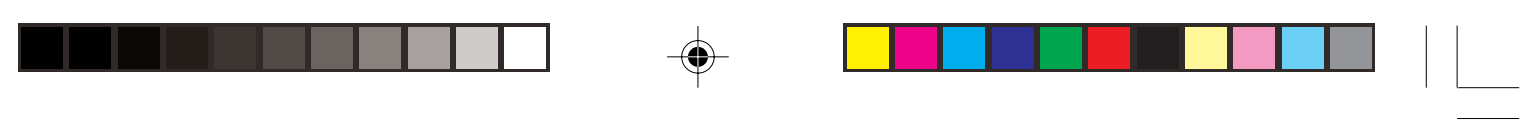

ECO-JOURNALISM AND SECURITY

for many, the chance to travel out of Fiji and see a foreign country which they only read about in the Bible. Then Lolohea disappeared. The people were left with no jobs and worse, no money. (Fiji Times, 2006a).

Personnel returning from Iraq called for Lolohea to be investigated by police, but Lolohea has not returned to Fiji from Kuwait. By early 2006, the issue had not been formally referred to police by the Labour Ministry and Fiji police have since confirmed that they do not have jurisdiction to arrest or charge Lolohea for a breach of contract. (Fiji TV 2005; Fijilive, 2006c). During the year, disappointed workers have returned home from Kuwait in 2006 without jobs.

Meridian is not the only recruiting company to face criticism. Global Risk Strategies proudly says it has remitted over US\$4 million into Fiji soldiers' bank accounts, but they too have faced complaints over slow payment or misrepresentation of conditions. In 2004, lawyers for a group of 50 former soldiers who were contracted by Global Risk Strategies for deployment to Iraq, says the Fijian recruits are owed US $\$ 12.5$ million in wages. Lawyer Tevita Fa threatened to bring legal action against Global Risks after the men were promised lucrative pay in Fiji but were offered contracts with much lower wages when they got to Iraq (Fiji Sun, 2004; RNZI, 2004).

\section{Insurance payouts}

The greatest risk of course is not delayed pay packets in Iraq, but the chance you will have your head blown off. For rural villagers in Fiji, the insurance payouts for death and injury are a massive sum. In Suva, local wits jokingly encourage relatives to go and get killed for the good of the family.

In February 2004, the British company Global Risks Strategies announced that it would pay more than US\$150,000 in compensation to the family of Tomasi Ramatau of Navunievu village in Bua. Ramatau was killed in a mortar attack at Baghdad International Airport while his colleague Tevita Tukana of Lakeba was wounded in the leg by shrapnel from a mortar round. Ramatau left a widow Una and six-month-old baby, Taniela.

In May 2004, two other employees of Global Risks Strategies-Kelepi Qaranivalu and Emori Vunibokoi-were killed while escorting a convoy in Iraq. Both soldiers had previously served in UN peacekeeping operations with the First Fiji Infantry Regiment in Lebanon (UNIFIL) and the Second 

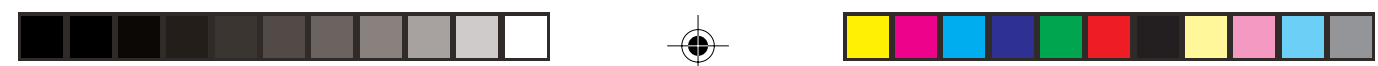

\section{ECO-JOURNALISM AND SECURITY}

Battalion in Sinai (MFO). Global Risks announced that each of their families received F\$275,000 (US\$153,000) from Lloyds of London.

Meanwhile, the wounded face long-term health problems on their return home. Isaia Nainoca Mate from Naqalotu village in Kadavu was one of three guards escorting oil tankers from Turkey to Iraq. He was $10 \mathrm{~m}$ from the explosion when a roadside bomb blasted the convoy. His two Fijian colleagues were killed and Mate was left with damage to his hearing and leg injuries:

Sometimes I wake up suddenly in the middle of my sleep thinking I heard some loud noises. I can't do long walks now as the lower part of my left leg is still numb. (Fiji Times, 2005f).

The then Minister for Labour Kenneth Zinck made a flying visit to Kuwait in 2005 and stated that his ministry supported workers travelling to Iraq and Kuwait:

All the workers are covered by insurance for work related injuries and deaths. The insurance is arranged by the employing companies and that is a mandatory part for the contracts which are attested by my ministry. These workers are also required to be repatriated by these companies when their contract period expires or in case of death. (Fiji government, 2005b).

Church and non-government organisations in Fiji have spoken out about the hazards of the mercenary trade. Reverend Akuila Yabaki, director of the Citizen's Constitutional Forum (CCF), has said:

The CCF has from the beginning opposed the recruitment of former soldiers by Global Risks Strategies for its profit making security business in Iraq. CCF calls on the representative of Global Risks in Fiji, Colonel Sakiusa Raivoce, to seriously reconsider whether his work of promoting the interests of Global Risks in Fiji in worthwhile in view of the death and serious injuries that have occurred and is likely to recur in future. The situation in Iraq is getting dangerous and soldiers should be withdrawn. This is the responsibility of the Fijian Government because it had encouraged the recruitment activities of Global Risks from the start. (Yabaki, 2004).

Commenting on the number of Fijian casualties in Iraq, an editorial in the 
Fiji Sun, noted: 'The death of a soldier fighting for his country can be justified. But the death of a man fighting only for money is a tragedy that his employers - and those who pay them - must carefully consider.' (Fiji Sun, 2004). The number of casualties increased rapidly in 2006 , as the security situation continued to deteriorate in Iraq. A series of attacks in mid-2006 left another 11 men dead, and many others wounded:

April 18: Four Fijians were killed in an insurgent ambush on a convoy carrying oil equipment and other supplies to a US military base at Kirkuk, in the north of Iraq. Malakai Sekibureta and Iosefo Cagi were employees of Genric Security. Manasa Navakaro and Kelemedi Dreuvakabalawa were originally employed in Fiji by Controlled Risks, had completed their original contracts and were due to return home, but transferred to International Security Company (ISC) in Kuwait to earn extra funds before returning to Fiji.

April 30: Josaia Taka Seniyasi, Sevuloni Nawaduadua and Alifereti Cereilagi were killed in a roadside bomb. They were escorting a convoy of trucks carrying reconstruction materials when the convoy was attacked southeast of Baghdad.

May 2: Viliame Ravatugaga died in a bomb blast north of Baghdad.

June 9: Vilisoni Gauna, Penaia Vakaotia and Mikaele Banidawa, security guards employed by ArmorGroup, were killed in a roadside bombing north of Baghdad. Their vehicle hit an IED which was hidden in a culvert (RNZI, 2006; Fijilive 2006).

After the attacks, the security firm Armor Group stated that the spate of incidents suggested Fijian personnel were being directly targeted by insurgents (Fiji government 2006). The series of attacks also raised concern in the Fiji government, with Prime Minister Laisenia Qarase urging people to stay at home to develop the country rather than travel to the Middle East:

If they make good use of their resources, surely they will earn the same amount they work for in Iraq. (Radio Australia, 2006).

Faced with public criticism that recruiting firms were not being regulated, the new Minister for Labour Krishna Datt called for people intending to work in Iraq to check with his ministry before signing any contract:

We want to ensure that the recruitment operation is within the law. And if it is so, then we can not stop people from seeking employment. But 

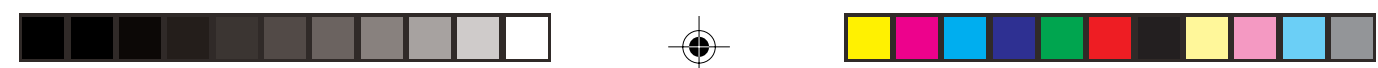

\section{ECO-JOURNALISM AND SECURITY}

the ministry should be able to study the contract of employment first. (Fiji government, 2006b)

\section{Joining the British army}

Private companies are not the only people recruiting Pacific Islanders. As the US and British armed forces fail to meet their recruiting targets, they've been expanding their recruitment overseas. There are currently more than $2000 \mathrm{Fi}-$ jian soldiers in the British Army, and the UK government is expanding recruitment in its former colony. In 2004, the British defence ministry even sent recruiting teams to Fiji to do initial fitness and aptitude tests, cutting the costs of selection for poor Fijian villagers who could not afford to fly to London to sign up. Defence analyst Major Charles Heyman noted:

There is a long military tradition in Fiji and many serve today because their fathers and grandfathers did. The Fijians have been an essential part of the British Empire and what they are doing, basically, is filling the vacant slots in the British Army because we cannot recruit enough from the UK itself. This happened very successfully in the 1960s and 70 s and is working very well again today. The truth is they are just normal guys, just like our guys. They make very, very good infantry soldiers. (BBC, 2004)

Some 60 Fijians have been sent to Iraq as part of the British Army deployments near Basra in the southern province of Al-Muthanna-supposedly a secure area away from the main fighting in Sunni areas and Baghdad (RFMF Army News, 2004). But the risks are still there, as shown by the deaths of Fijians serving with British forces. In November 2004, US forces launched an assault against Fallujah, causing massive civilian casualties. As US forces prepared to attack the town, British forces were redeployed from the south of Iraq to Baghdad, to fill the gap left by the US mobilisation. Private Pita Tukutukuwaqa of the British Army's Black Watch regiment was one of three soldiers in a Warrior armoured vehicle on routine patrol at Iskandariyah, near Camp Dogwood in Baghdad, when they were hit by a roadside bomb. Private Tukutukuwaqa was airlifted to a military hospital in Baghdad, but died of his wounds. Two other Fijian soldier serving with British forces near Basra in the south of Iraq have since been killed in separate roadside bombings: Private Josefa Lewaicei of the Royal Anglican Regiment in a May 2006 (Fiji

58 PACIFIC JOURNALISM REVIEW 12 (2) 2006 

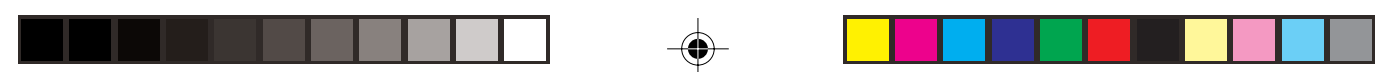

ECO-JOURNALISM AND SECURITY

Times, 2006) and Gunner Samuela Vanua of the Regiment Royal Artillery in September 2006.

\section{UN deployments}

The current recruitment of Fijian personnel by private security corporations came after an invasion that had been launched by the United States and its allies without the endorsement of the UN Security Council. In contrast, Fiji's international peacekeeping operations have all been conducted under the mandate and authority of the United Nations. In 2003, there was widespread public debate in Fiji over whether RFMF troops should join the US-led coalition in Iraq, but the government of Fiji decided to maintain its ties to the United Nations. In December 2004, Fiji sent the first contingent of 134 RFMF troops to Iraq, but under the banner of the United Nations Assistance Mission to Iraq (UNAMI) and not as part of the 'Coalition of the Willing'. ${ }^{5}$ Since the first UNAMI deployment in 2004, there have been two further rotations of troops and a further 34 soldiers were deployed in August 2006 to protect UN civilians working in Iraq.

Fijian soldiers provide security for UN facilities at the Diwan and Villa compounds in Baghdad where UN officials operate, and there are plans for further deployments to UN facilities in Erbil and Basra. (RFMF Army News, 2004). The contingent suffered its first death in March 2006, when Corporal Sekuri Soko died of a suspected heart attack.

Because of insurgent attacks, the Fijian UN troops in Baghdad cannot move around town. They live on a daily allowance of $F \$ 65$ and are suffering boredom and frustration, even though they are regularly rotated. In response to these concerns, Fiji's Cabinet approved an increase of Location Allowance (LA) for RFMF soldiers serving in the Middle East in early 2006. Returning to Fiji, Fiji battalion commander Colonel Meli Saubulinayau said soldiers working for the United Nations in Iraq are depressed because of the prisonlike environment they live in: 'It's like prison except that we provide the guards' (Fiji Times, 2005g).

\section{Bougainville and the privatisation of security}

The current operations in Iraq are part of a wider trend for private companies to be delegated responsibility by governments for internal security operations. This can range from the use of commercial security firms to guard 

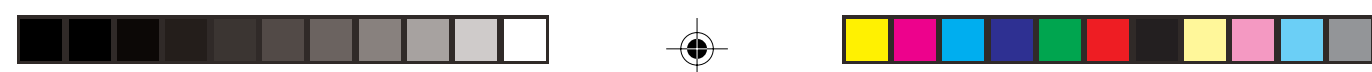

\section{ECO-JOURNALISM AND SECURITY}

government facilities to the provision of supplies or the hiring of mercenaries by foreign corporations.

In the Pacific region, the clearest example of the privatisation of security came with the 1997 Sandline crisis in Papua New Guinea (Dinnen, 1998). The crisis developed after the conflict in Bougainville between the Papua New Guinea Defence Force (PNGDF) and the Bougainville Revolutionary Army (BRA) had come to a military stalemate, with the PNG government unable to defeat the independence movement. The government of then Prime Minister Sir Julius Chan, fearing the war was creating divisions and mutiny in the PNGDF, and concerned about international criticism of human rights abuses by government forces, turned to a foreign corporation for assistance in recruiting mercenaries, purchasing military equipment and recapturing the giant Panguna copper and gold mine (which had been closed by BRA activity).

The London-based corporation Sandline International recruited personnel from Executive Outcomes, one of a range of private corporations established by former military personnel to wage warfare on behalf of corporate backers or to protect key resource projects like diamond mines, oil fields or mining projects. Operating widely in Africa, Executive Outcomes sent African mercenaries, helicopters and weaponry to Port Moresby, in preparation for an armed assault on BRA areas and Bougainville villages.

The Sandline saga ended in failure, when the plot was revealed in the media and elements of the PNGDF led by Brigadier General Jerry Singirok rose up in protest and refused to allow the mercenaries to commence their operations in Bougainville (Dorney, 1998; O'Callaghan, 1999). In March 1997, the mercenaries were captured at gunpoint by PNGDF soldiers and expelled from the country. The 1997 Sandline crisis was a significant turning point in Papua New Guinea politics, contributing to Prime Minister Chan's loss of office in July 1997 elections and leading to peace negotiations to settle the Bougainville war. Ironically, the leader of the failed mercenary operation, Colonel Tim Spicer, has reappeared in Iraq with new contracts for private security (Chaterjee, 2004).

The attempt to involve Sandline in the Bougainville crisis was not the only attempt to use private corporations for military and security operations in the Pacific. In the early 1990s, PNG politicians tried to recruit overseas corporations such as Defence Services Ltd (DSL) to police mining operations in the highlands of Papua New Guinea (Dinnen, 2001). ${ }^{6}$ The Sandline 60 PACIFIC JOURNALISM REVIEW 12 (2) 2006 

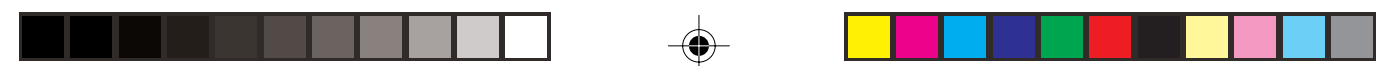

ECO-JOURNALISM AND SECURITY

and DSL cases highlight the capacity of transnational corporations to lobby behind the scenes and influence policy - a significant issue for democratic accountability. According to ANU researcher Sinclair Dinnen:

The [mining and petroleum] industry had a well-organised and wellfunded lobbying capacity. The chamber was able to gain access to the commanding heights of the State, including the Prime Minister, senior ministers and high ranking officials in the bureaucracy and police. Few domestic groups could match either the industry's resources or its organisation. Defence Services, another transnational, had similar access and appears to have taken its lobbying efforts to the extent of providing overseas trips for key decision makers. (Dinnen, 2001, p.137).

The use of private corporations rather than state-run military and police forces raises important questions of accountability, because the private corporation can hide its operations (and profits) behind claims of 'commercial secrecy'. As always, it is the soldiers on the ground who suffer, while corporate profits are siphoned home to London or New York. Breaches of human rights by private mercenaries do not come under the judicial scrutiny of a court martial or police disciplinary procedure. Above all, taxpayer funds used for these expensive corporate operations often come at the expense of improving the conditions and equipment of existing police and military forces, which weakens their capacity and justifies renewed corporate incursions into the security sector.

\section{Ronin-missionaries, mercenaries or misfits?}

The official and unofficial deployments to the Middle East have been widely accepted in Fiji, because of the significant remittances flowing to rural villagers from their sons and husbands serving overseas. But the privatisation of security has brought new problems for the government of Fiji, with news in late 2005 that former RFMF soldiers were once again working in Bougainville. In November 2005, reports came through that eight Fijians were working in the bush in Siwai district of Bougainville. Early reports claimed they had entered Bougainville as missionaries but were training a militia for alleged conman Noah Musingku, with the promise of up to F\$1 million each as payment. ${ }^{7}$ (Musingku, the operator of the failed U-Vistract pyramid scheme, has established a base near Tonu and has been recruiting young Bougainvilleans

PACIFIC JOURNALISM REVIEW 12 (2) $2006 \mathbf{6 1}$ 


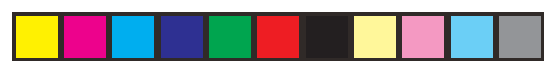

\section{ECO-JOURNALISM AND SECURITY}

to provide security for his operations.) The Fiji government has not formally confirmed that the men are mercenaries, but there is concern and extensive diplomatic action as the group includes former members of the now disbanded 1st Meridian Squadron (Counter Revolutionary Warfare Unit or CRW), an elite RFMF unit created by Sitiveni Rabuka after the 1987 coup. Fiji and PNG government officials have since tried to encourage the Fijians to leave Bougainville. Three Fijians have returned home, but at the time of writing five others remain in the isolated area in central Bougainville.

In February 2006, a further 12 Fijians were arrested in Honiara and deported home, after they tried to get to Bougainville through the Solomon Islands. Through the Melanesian Spearhead Group, the three governments have now moved to strengthen immigration controls and border security to halt the transit of potential mercenaries into Bougainville.

Fiji and PNG government officials have since tried to encourage the Fijians to leave Bougainville. By June 2006, the Fijians realised that their promised millions were a fantasy, and Musingku fled from his base after falling out with his Bougainville protectors. Three of the Fijians have returned home, but at the time of writing five others remain in the isolated area in central Bougainville, fearful of leaving because they face prosecution for breaches of PNG's immigration and security laws. Fijilive news service has reported that the men were former Fijian military personnel and have links to the private security firm Ronin Security Ltd. (Fiji live, 2005c).

Ronin was created by Aliki Moroca, Samu Railoa and other former members of the Counter Revolutionary Warfare Unit (CRW), with support from Ilisoni Ligairi, a retired soldier who had served in the British SAS for many years. ${ }^{8}$ Ligairi led those members of the CRW who stormed into Parliament during Fiji's May 2000 coup, when the Labour-led coalition government was overthrown and Prime Minister Mahendra Chaudhry and other government MPs were held hostage for 56 days. Ronin is the Japanese term for a samurai warrior who has lost his job, after the death of his lord or having lost his master's favour. The ronin is often forced to wander the countryside, selling his service. Many ronin become bandits or law breakers, were greatly feared and assumed to be without honour.

\section{Conclusion}

The war in Iraq is a tragedy for the people of the Middle East, but the ripples have spread throughout the world. In February 2003, thousands of Pacific 62 PACIFIC JOURNALISM REVIEW 12 (2) 2006 

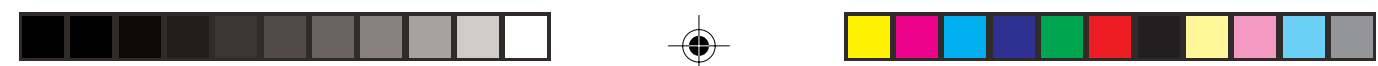

ECO-JOURNALISM AND SECURITY

Islanders joined the global protests against the looming war in Iraq (Maclellan, 2003). Today, Iraq remains a global concern and the ongoing chaos caused by the US occupation is spreading insecurity as far as the South Pacific.

\section{Notes}

1 Details for casualties among private contractors can be found at: http:// icasualties.org/oif/Civ.aspx

2 The Israeli attack on the Fijian camp was deliberate, or as the UN Secretary General diplomatically wrote to the UN Security Council at the time: 'While the possibility cannot be ruled out completely, the pattern of impacts in the Qana area makes it unlikely that the shelling of the United Nations compound was the result of technical and/or procedural errors' (Boutros Boutros Ghali, 1996).

3 From a 2004 US State Department list of security companies operating in Iraq, republished on: www.globalsecurity.org/military/library/report/2004/ iraq_securitycompanies.htm

4 Ibid.

5 The other country to send troops for UNAMI is Georgia, which has sent 500 troops of its 3rd Shavnabada Batallion.

6 DSL was taken over by ArmorGroup in 1997.

7 A detailed description of the ongoing events in Bougainville can be found on the Wikipedia website at: http://en.wikipedia.org/wiki/Fijian mercenaries in Bougainville

8 'Ligairi had joined the British Army in the early 1960s and seen service in Ireland, Saudi Arabia, Kenya and Oman as a member of the Special Air Service. He retired to Fiji in 1984 where some three years later he became founding commander of the 70-man anti-terrorist Counter Revolutionary Warfare Unit established by Fiji's former strongman Sitiveni Rabuka, as a palace guard to protect his 1987 coups.' (Robertson \& Sutherland, 2001).

\section{References}

ASPI (2005). War and profit—doing business on the battlefield. Canberra: Australian Strategic Policy Institute.

BBC (2004, November 9). Fiji's 'unsung heroes' of UK army. BBC News Online.

Blackwater website: www.blackwaterusa.com (Retrieved 17 July 2006).

Bolaitiki, M. (2004, January 20). Fiji mercenaries question pay discrepancies, Fiji Sun.

Boutros Boutros Ghali (1996). Letter from UN Secretary General Boutros Boutros Ghali to the President of the UN Security Council, May 7, UN document S/1996/ 337.

Centre for Public Integrity (2002). The business of war. www.publicintegrity.org/bow/ Chatterjee, P. (2004, June 9): Controversial commando wins Iraq contract. Corpwatch. 

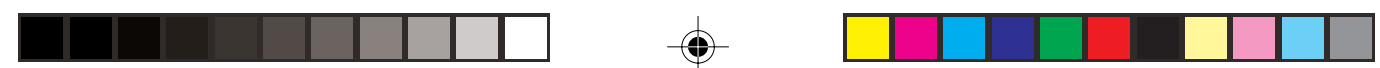

\section{ECO-JOURNALISM AND SECURITY}

Dinnen, S. (2001). Law and order in a weak state — crime and politics in Papua New Guinea, Adelaide: Crawford House.

Dinnen, S., A. Regan and R. May (1998). Challenging the state-the Sandline affair in PNG, NCDS Pacific Policy Paper No.30. Canberra: ANU.

Dorney S. (1998). The Sandline affair. Sydney: ABC.

Fiji Government (2005a, April 26). News Briefs, Fiji Government Online.

Fiji Government (2005b, April 19). Kuwait and Iraq workers are insured-Zinck. Media release.

Fiji Government (2006a, May 5). News Briefs, Fiji Government Online.

Fiji Government (2006b, July 10). News Briefs, Fiji Government Online.

Fijilive (2005a, May 2). Wrong body sent to Fiji in Iraq snafu.

Fijilive (2005b, May 12). Fiji government orders probe of recruiting firm.

Fijilive (2005c, November 17). Mercenaries may have link to 2000 Fiji coup.

Fijilive (2006a, February 16). Demobilised Fiji troops pose employment problem.

Fijilive (2006b, March 12). Overseas opportunities thin Fiji military ranks.

Fijilive (2006c, March 16). Lolohea cannot be investigated.

Fijilive (2006d, April 20). Four Fijians die in Iraq ambush.

Fiji Sun (2003, December 23). Fijians survive bloody shoot-out.

Fiji Sun (2004, February 10). Beware the danger of mercenary duty in Iraq, Editorial.

Fiji Times (2003, December 26). Iraq guards sent home in disgrace.

Fiji Times (2004, January 20). Iraq guards come home to pay battle.

Fiji Times (2005a, February 5). Fiji guards enjoy rebuilding work.

Fiji Times (2005b, January 19). Worker exodus a drain on Fiji manpower.

Fiji Times (2005c, March 21). New British security firm hiring in Fiji.

Fiji Times (2005d, April 13). Fiji mercenaries earn \$3 million in Iraq.

Fiji Times (2005e, July 7). Officers reveal Iraq woes.

Fiji Times (2005f, May 1). Iraq blast haunts Fiji contract worker.

Fiji Times (2005g, May 9) It's like living in jail.

Fiji Times (2006a, February 7). Duped job seekers deserve justice, Editorial.

Fiji Times (2006b, May 17). Another Fiji soldier killed in Iraq.

Fiji TV National News (2005, December 30). Police confirm, no investigation on Lolohea.

Isenberg, D. (2006). The good, the bad and the unknown: PMCs in Iraq. Presentation at Guns ' $n$ gates: The role of private security actors in armed violence. Bonn: Germany, February 9-10.

Halapua, W. (2003). Tradition, lotu and militarism in Fiji. Suva: Fiji Institute of Applied Studies.

Komai, M. (2004, December). Rebuilding Iraq, Islands Business.

Maclellan, N. and P. Mares (2006, April). Remittances and labour mobility in the Pacific. Working Paper, Pacific Labour and Australian Horticulture project, Swinburne University. www.sisr.net/cag/projects/pacific.htm

Maclellan, N. (2003, February). Pacific islanders join global protests against the war, Pacific News Bulletin, 18(2), p. 1.

64 PACIFIC JOURNALISM REVIEW 12 (2) 2006 
Nadore, I. (2005, April 26). Fiji guards die in Iraq-pray for me, says dad before dying, Fiji Sun.

O’Callaghan, M. (1999). Enemies within. Sydney: Doubleday.

Pareti, S. (2005, April). Fiji's long, risky road to Kuwait, Islands Business.

Radio Australia News (2006, June 13). Fiji's PM urges former soldiers to resist working in Iraq.

RFMF Army News (2004, December). 1FIR takes over the UNAMI headquarters.

RNZI News (2004, February 24). Fiji mercenaries to sue British firm for back wages. RNZI News (2006, April 20). Fiji PM pays tribute to security guards killed in Iraq.

Robertson, R. and W. Sutherland (2001). Government by the gun: the unfinished business of Fiji's 2000 coup. Leichhardt: Pluto.

Skylink Air and Logistics Support (USA) Inc website: www.skylink-usa.net (Accessed July 2006).

Teaiwa, T. (2005). Articulated cultures - militarism and masculinities in Fiji during the mid-1990s, Fijian Studies 3 (2), pp. 201-222.

Tyson, A. (2005, April 23). Private security workers living on edge in Iraq-downing of helicopter shows heightened risks, The Washington Post, p. A01.

US Embassy (2005). Media release, Suva, April.

Yabaki, A. (2004, May 3). Death of two Fiji soldiers in Iraq, CCF press release.

Nic Maclellan is an independent journalist, broadcaster and researcher. An earlier version of this article was published on the Nautilus Institute's Austral Policy Forum at the Royal Melbourne Institute of Technology (RMIT), 6 April 2006.

www.nautilus.org/ rmit/forum-reports/0611a-maclellan.html

nicmaclellan@optusnet.com.au

PACIFIC JOURNALISM REVIEW 12 (2) $2006 \mathbf{6 5}$ 